\title{
Effect of Phaleria macrocapa on Atrophy and Apoptosis of Intestinal Mucous Cell and Phalerin Concentration at Portal Vein and Systemic Circulation in Adenocarcinoma Mice following Adriamycine and Cyclophosphamide Treatment
}

\author{
Titik Sumarawati ${ }^{1, *}$, Ignatius Riwanto ${ }^{2}$, Soeharyo Hadisaputro ${ }^{3}$, Edi Dharmana ${ }^{4}$, Taufiqurachman Nasihun ${ }^{5}$
}

Titik Sumarawati ${ }^{1, *}$, Ignatius Riwanto ${ }^{2}$, Soeharyo Hadisaputro ${ }^{3}$, Edi Dharmana ${ }^{4}$, Taufiqurachman Nasihun $^{5}$

'Department of Chemistry Medical Faculty of Sultan Islamic Agung University, INDONESIA. ${ }^{2}$ Department of Surgery, Medical Faculty of Diponegoro University, INDONESIA. ${ }^{3}$ Department of Internal Medicine Medical Faculty of Diponegoro University, INDONESIA.

${ }^{4}$ Department of Parasitology Medical Faculty of Diponegoro University, INDONESIA. ${ }^{5}$ Department of Biochemistry Medical Faculty of Sultan Agung Islamic University, INDONESIA.

\section{Correspondence}

Titik Sumarawati

Department of Chemistry Medical Faculty of Sultan Islamic Agung University, INDONESIA.

E-mail: sumarawati@gmail.com

History

- Submission Date: 24-01-2020;

- Review completed: 11-02-2020;

- Accepted Date: 05-03-2020

DOI : 10.5530/pj.2020.12.90

Article Available online

http://www.phcogj.com/v12/i3

\section{Copyright}

(C) 2020 Phcogj.Com. This is an openaccess article distributed under the terms of the Creative Commons Attribution 4.0 International license.

\begin{abstract}
Introduction: Chemotherapy has been proven capable of reducing breast cancer cell progression; however the adverse effect also emerging. Thus, diminish those adverse effects with botanical product Phaleria macrocarpa (PM) as adjuvant therapy is necessary. Objective: This study aimed to evaluate the effect of PM treatment in combination with adriamycine and cyclophosphamide (AC) on intestinal apoptosis and their correlation with phalerin concentration in systemic circulation. Methods: In the experimental study, 30 female mice with adenocarcinoma were assign into 5 groups: Neg-G, only given aquadest; Portal vein group (PMV-G) and systemic circulation groups (PMC-G), were administered PM 0.146mg/day; Portal vein group (PMACV-G) and systemic circulation group (PMACC-G), were administered Phaleria macrocarpa 0,146 mg orally, Adriamycine 0,013 mg and Cyclophosphamide 0,0156 mg singgle dose intravenously. Phalerin concentration was measured by HPLC methods at minute 30,60, $90,120,150$, and 180 after treatment. At the end of study, intestinal mucous cell apoptosis was identified by TUNEL methods. Results: independent t test analyses showed that index of apoptosis of intestinal mucous cell were significant higher in PMAC-G compared to that of Neg-G and PM-G, $p<0.05$. In contrary, phalerin concentration in PMAC-G was significant lower compared to that of PM-G, $p<0.05$. The Pearson analysis indicated the inverse correlation $(r=$ $-736, p>0.05)$ between apoptosis index with phalerin concentration. Conclusion: Treatment of $\mathrm{PM}$ in combination with $\mathrm{AC}$ has been proven able to increase intestinal mucous cell apoptosis and decrease phalerin concentration. However, the inverse correlation didnot exist.
\end{abstract}

Key words: Atrophy, Apoptosis, Phalerin, Concentration.

\section{INTRODUCTION}

Breast cancer in female remain constitute the second leading cause of death following lung cancer. ${ }^{1}$ In general, management of breast cancer utilizes various approaches such as surgery, radiation, endocrine treatment, immunotherapy, and chemotherapy according to its clinical stage. ${ }^{2}$ Chemotherapies were most frequently used in breast cancer management is combination of Adriamycine and Cyclophosphamide (AC) or Cyclophosphamide, Adriamycine, and Fluorourasil $(\mathrm{CAF}) .^{3}$ Considering those regimens were incapable of differencing accurately the cancer and the normal cell, therefore, albeit chemotherapy was effective in tumor regression, unfortunately in the same time the deleterious adverse effects also emerging. ${ }^{4}$ Various adverse effects such as reducing blood cell number, mouth sore, intestinal disorder, and hair fall are the consequence of cell death induced by those regiments..$^{5}$ Accordingly, an effort to diminish those adverse effects with an adjuvant therapy deriving from botanical product such as Phaleria macrocarpa (PM) is necessary. Some evidences indicated that PM possess pharmacological effects such as anti-diabetes, anti-inflammation, antioxidant, anti-cancer, and in the same time also have protective effect on organs damages. ${ }^{6}$ However, it is remaining unclear whether the effect of AC treatment in combination with PM also damage other organs such as intestinal mucous cells, and is there any correlation between the severity of intestinal cell damage and phalerin absorption which is marked by phalerin level in systemic circulation.

Adriamycine or known as Doxorubicin Hydrochloride constituting a high toxic substance on cancer cells. The cytotoxicity of adriamycine is worked due to inhibition of tophoisomerase 2 activity, induce apoptosis and necrosis, therefore disturb deoxyribo nucleic acid (DNA) and Ribose Nucleic Acid (RNA) replication and halt cancer proliferation. ${ }^{7}$ The toxicity of adriamycine, aside from induce apoptosis and necrosis on malignant cells, also cause bone marrow depression and damage to intestinal mucous cells, ${ }^{7,8}$ by which intestinal absorption potency is inhibited. Study in rats were injected by Doxorubicin demonstrated that the histological score of intestinal damaging cells were as high as $8,0 \pm 0,81$ and the length of villus reduced were as short as $43,3 \%$ $\pm 13,7 \%$. In addition, the numerous evidences

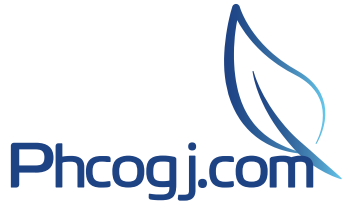

Cite this article: Sumarawati T, Riwanto I, Hadisaputro S, Dharmana E, Nasihun T. Effect of Phaleria macrocapa on Atrophy and Apoptosis of Intestinal Mucous Cell and Phalerin Concentration at Portal Vein and Systemic Circulation in Adenocarcinoma Mice following Adriamycine and Cyclophosphamide Treatment. Pharmacog J. 2020;12(3):603-10. 
also demonstrated that the damaging cells due to adriamycine are attributable to increase in reactive oxygen species (ROS) concentration and thus oxidative stress. ${ }^{8,9}$

Cyclophosphamide $(\mathrm{CP})$ is widely used as anti-cancer is an alkylating agent, which active in resting phase (nonspecific) of cell cycle. The toxicity of CP is characterized by DNA and RNA strand cross-linking and inhibition of protein synthesis induced by phosphoramide mustard. ${ }^{10,11}$ Phosphoramide mustard is a metabolite of CP that possess double function, which bind to $\mathrm{N}-7$ group of guanin and phosphat backbone of DNA and therefore induce cellular apoptosis. ${ }^{12}$ In addition, Selby PJ, et al. also reported that treatment of CP intra venous with dose $7 \mathrm{~g} \mathrm{~m}^{-2}$, was proven incapable of altering the intestinal permeability and able to reduce cellular damage following treatment of anti-cancer melphalan. ${ }^{13}$ On the other hand, there are various studies demonstrated that chemotherapeutic agent was proven induce mucositis and result in apoptosis of intestinal somatic and regenerative stem cell, villous atrophy, and enterocyte mass. ${ }^{14,15}$ Consequently, chemotherapeutic agent such as $\mathrm{CP}$ in combination with adriamycine is able to induce intestine cells permeability alteration and its absorption rate. Accordingly, addition of Phaleria macrocarpa extract containing Phalerin as anti-cancer constitute a rational choice in order to enhance the efficacy of CP modality and diminish its side effect at ones.

Phaleria macrocarpa is Indonesian indigenous plant, traditionally utilized to cure diabetic, rheumatic, kidney diseases, and various type of cancer. ${ }^{16}$ Phytochemical analysis on PM demonstrated that various substance such as Phalerin, gallic acid, Icaricide C, magniferin, mahkoside A, dodecanoic acid, palmitic acid, des-acetylflavicordin-A, flavicordin-A, flavicordin-D, flavicordin-A glucoside, ethyl stearate, lignans, alkaloids and saponins were contained in PM. ${ }^{16}$ Several evidences also indicated that treatment of PM in combination with $\mathrm{AC}$ have been proven capable of increasing immunologic parameter in breast cancer. ${ }^{17}$ In addition, treatment of PM on adenocarsinoma $\mathrm{CH} 3$ mice after treating with $\mathrm{AC}$ also demonstrated that $\mathrm{PM}$ was able to enhance immune response. ${ }^{16}$ Another study was reported by Riwanto also suggested that PM treatment in combination with AC synergistically able to reduce tumor cell growth and proliferation mediated by increase in apoptosis, as well as protect normal liver and kidney organ from damage. ${ }^{6}$ The dose of adriamycine was utilized in that study $60-75 \mathrm{mg} / \mathrm{m}^{2}$ and Cyclophosphamide was $100-2000 \mathrm{mg} / \mathrm{m} .{ }^{13}$ Considering, the successful rate of oral medication is extremely affected by absorption, dose, and availability of active substances on action site, ${ }^{18}$ therefore, phalerin, the prominent active substance of PM, in portal vein and systemic circulation should be determined aside from intestinal cell apoptosis. Objective of the study is to evaluate the effect of AC treatment in combination with PM on apoptosis, level of atrophy of intestinal mucous cell, and phalerin concentration in portal vein and systemic circulation on adenocarcinoma $\mathrm{CH} 3$ mice.

\section{METHODS}

In the Posttest Only Control Group design, 30 adenocarcinoma mammae $\mathrm{CH} 3$ female mice, 2-4 months old, with 20-40 gram body weigh were assigned into 5 groups randomly, 6 mice of each. (1). Negative control group (Neg-G), only given aquadest. (2). Phaleria macrocarpa group, this group divided into two groups, that were portal vein group (PMV-G) and systemic circulation groups(PMC-G), to these groups were administered PM $0.146 \mathrm{mg} /$ day. (3). PM in combination with AC group divided into two groups i.e. portal vein group (PMACV-G), and systemic circulation group (PMACC-G), to these groups were administered PM 0,146 mg, Adriamycine 0,013 $\mathrm{mg}$ and Cyclophosphamide 0,0156 mg. Treatment of PM alone and in combination with AC was given orally for 21 days, meanwhile AC injected intravenously at day one as part of every 3 weeks for 4 cycles program. At minute of 30, 60, 90, 120, 150, and 180 following initial treatment, blood sample was serially taken from portal vein and systemic circulation to evaluate phalerin concentration.
Phalerin concentration was measured with High Performance Liquid Chromatography (HPLC; Knauer), Lichrosorb Rp 18 (250 x 4 mm, $5 \mu \mathrm{m})$ column. At the end of the treatment, all mice were sacrificed and the intestinal tissue was taken to measure grading score of intestinal mucous cell atrophy and apoptosis. The study was performed following approved by the ethics committee of Medical faculty, Sultan Agung Islamic University.

\section{Inoculation of breast adenocarcinoma cells}

One million cell of breast cancer was inoculated on mice after one week acclimatization. Furthermore, the $0.2 \mathrm{ml}$ tumor pulp derived from breast cancer was injected into fat pad of mice and to be leaved for 5 days. In day 6 all mice have tumor mass and therefore recruited as samples.

\section{Phalerin extraction}

Phaleria macrocarpha taken from Tasikmalaya west Java was dried, crushed, and extracted by Soxhlet methods and utilize ethanol as a solvent. The process was run in 8-10 times circulation. Ethanol was disolvated by using a rotary evaporator and dried in an oven at $40^{\circ} \mathrm{C}$ for one hour. The extract was diluted by aquabidest at the concentration of $0.2 \mathrm{mg} / \mathrm{ml}$.

\section{Measurement of intestinal mucous cell atrophy}

Smooth intestinal mucous cell atrophy was calculated based on haematoxylin and eosin (H\&E) staining preparation and examined by light microscopic in 400 magnification. The grading score of intestinal mucous atrophy was determined by Maepheusen \& Pfeiffer methods and can be described in Table $1 .^{19,20}$

\section{Measurement of apoptosis index of intestinal mucous cell}

Aapoptosis index was identified by terminal deoxynucleotidyl transferase dutp nick end labeling (TUNEL) method. The findings of TUNNEL positive cells in each group were calculated (10 field slides) and examined by light microscopic in 400 magnifications.

\section{Measurement of phalerin concentration}

Two hundred micro liter of serum was aspirated from portal vein and systemic circulation added with $200 \mu \mathrm{L}$ mixture of $\mathrm{MeOH}$ and $\mathrm{CH} 3 \mathrm{CN}$ with 90:10 ratio, then Vortexed for 2 minutes and centrifuged at 10.000 rpm for 5 minute at $17^{\circ} \mathrm{C}$. The supernatant then taken and placed in eppendorf and dried in water bath at $50^{\circ} \mathrm{C}$ in nitrogen continuous flush out and then dissolved again in $\mathrm{MeOH} 200 \mu \mathrm{L}$. Fluid result from that process was filtered with $0.45 \mu \mathrm{m}$ Millipore filter and injected to HPLC at $20 \mu \mathrm{L}$ thereafter.

\section{Statistical analysis}

The statistical analysis was adopted in this study were Kruskal Wallis, followed by Chi square, and Mann Whitney (nonparametric), and

\section{Table 1: Histophatological Grading Score.}

\begin{tabular}{cl}
\hline Score & \multicolumn{1}{c}{ Microscopic findings } \\
\hline $\mathbf{0}$ & Normal Intestinal mucous cell \\
$\mathbf{1}$ & $\begin{array}{l}\text { Mucosa: villus blunting, loss of crypt architecture, sparse inflammatory } \\
\text { cell infiltration, vacuolization and edema. Normal muscular layer }\end{array}$ \\
& $\begin{array}{l}\text { Mucosa: villus blunting with fattened and vacuolated cells, crypt } \\
\text { necrosis, intense inflammatory cell infiltration, vacuolization and } \\
\text { edema. Normal muscular layer }\end{array}$ \\
& $\begin{array}{l}\text { Mucosa: villus blunting with fattened and vacuolated cells, } \\
\text { crypt necrosis, intense inflammatory cell infiltration, vacuolization and }\end{array}$ \\
& edema \\
& Muscular: edema, vacuolization, sparse neutrophil infiltration
\end{tabular}


independent $\mathrm{t}$ test (parametric). Significantly level was considered when $\mathrm{p} \leq 0.05$.

\section{RESULTS}

Following treatment with extract PM alone and PM in combination with $\mathrm{AC}$ for 21 days, the result of measurement of intestinal cells atrophy grading score and apoptosis index in each group are summarized in Table 2 .

The result of the study indicated that the highest intestinal cell mucous atrophy and apoptosis were in PMAC-G, followed by PM-G, and the lowest was in Neg-G. Kruskall wallis statistical analysis demonstrated that there were significant difference of atrophy grading score and apoptosis index amongst groups, $\mathrm{p}<0.05$. The difference intestinal mucous cell atrophy and index of apoptosis between two groups will be described below.

\section{Atrophy grading score of intestinal mucous cell}

By the Chi-Square statistical analysis indicated that the grading score of intestinal mucous cell atrophy in PM-G and PMAC-G was significant higher compared to that of Neg-G, $p<0.05$ respectively. Likewise, the grading score of intestinal mucous cell atrophy in PMAC-G was significant higher compared to that of PM-G, $\mathrm{p}<0.05$ (Figure 1).

\section{Apopttosis index of intestinal mucous cell}

By Mann Withney statistical analysis showed that apoptosis index in PM-G and PMAC-G were significant higher compared to that of Neg-G, $p<0.05$ respectively. Similarly, the apoptosis index in PMAC-G also showed significant higher compared to that of $P M-G, p<0.05$ (Figure 2).

\section{Phalerin concentration measurement}

In the present study also measure concentration of phalerin, a substance contained in phaleria macrocarpha, at portal vein, systemic circulation, and tumor tissue in order to evaluate the relationship between the severity of intestinal mucous cell apoptosis and atrophy and its potential phalerin absrption result from phaleria macrocarpha treatment.

\section{Phalerin concentration at portal vein}

The result of phaleria concentration measurement with HPLC methods at portal vein blood stream are summarized in Table 3 .

The phalerin concentration at portal vein can only be measured at minute 30,60 , and 90 , due to the death of all mice. The result of the present study showed that the highest phalerin concentration at portal vein of PM-G and PMAC-G were at minute 30 , followed by minute 60 , and the lowest was at minute 90 . These result demonstrated that phalerin concentration both in portal vein and systemic circulation decline in time fashion. Independent $t$ test indicated that phalerin concentration in PM-G at minute 30,60, and 90 were significant higher compared to those of PMAC-G, $\mathrm{p}<0.05$ (Figure 3).

\section{Phalerin concentration at systemic circulation}

The result of phaleria concentration measurement with HPLC methods at systemic circulation are summarized in Table 4.

The result of the study showed that phalerin concentration at systemic circulation of PM-G was highest in minute 30 , followed by 60,90 , 120,150 , and the lowest was at 180 minutes. These result showed that phalerin concentration was declined in time fashion. On the other

Table 2: Grading Score of Intestinal's Cell Atrophy and Mean of Apoptosis in Adenoma CH3 Female Mice Following PM and PMAC Treatment.

\begin{tabular}{|c|c|c|c|c|c|}
\hline \multirow{2}{*}{\multicolumn{2}{|c|}{ Variables }} & \multicolumn{3}{|c|}{ Groups } & \multirow{2}{*}{$\begin{array}{c}\mathrm{P} \\
\text { (Kruskall wallis }\end{array}$} \\
\hline & & $\begin{array}{c}\text { Neg-G } \\
\mathrm{N}=6 \text { (freq) }\end{array}$ & $\begin{array}{c}P M-G \\
N=6 \text { (freq) }\end{array}$ & $\begin{array}{l}\text { PMAC-G } \\
\mathrm{N}=6 \text { (freq) }\end{array}$ & \\
\hline \multirow{3}{*}{$\begin{array}{l}\text { Intestinal mucous cell } \\
\text { atrophy grading scale of } \\
\text { Macpherson and Pfeiffer }\end{array}$} & 0 & 6 & & & \\
\hline & 1 & & 6 & & 0.01 \\
\hline & 2 & & & 6 & \\
\hline \multicolumn{2}{|c|}{ Mean of Apoptosis Index } & $\begin{array}{c}\text { Neg-G } \\
N=6(\chi \pm S D)\end{array}$ & $\begin{array}{c}\text { PM-G } \\
\mathrm{N}=6(\chi \pm \mathrm{SD})\end{array}$ & $\begin{array}{c}\text { PMAC-G } \\
\mathrm{N}=6(\chi \pm S D)\end{array}$ & $\begin{array}{c}\mathrm{P} \\
\text { (Kruskall wallis) }\end{array}$ \\
\hline \multicolumn{2}{|c|}{$\begin{array}{c}\text { Indexes of Intestinal Cell Apoptosis } \\
(\%)\end{array}$} & $0,447 \pm 0,061$ & $0,597 \pm 0,031$ & $0,810 \pm 0,015$ & 0,001 \\
\hline
\end{tabular}

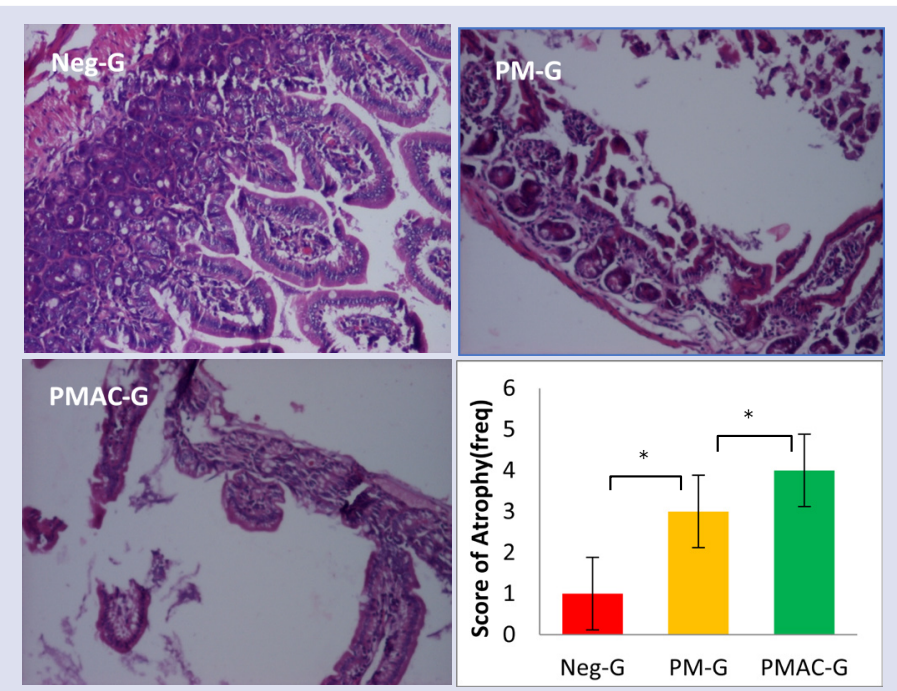

Figure 1: Score of Athropy of Intestinal Mucous Cell by HE staining methods. Mann Withney: ${ }^{*} p<0.05$. 


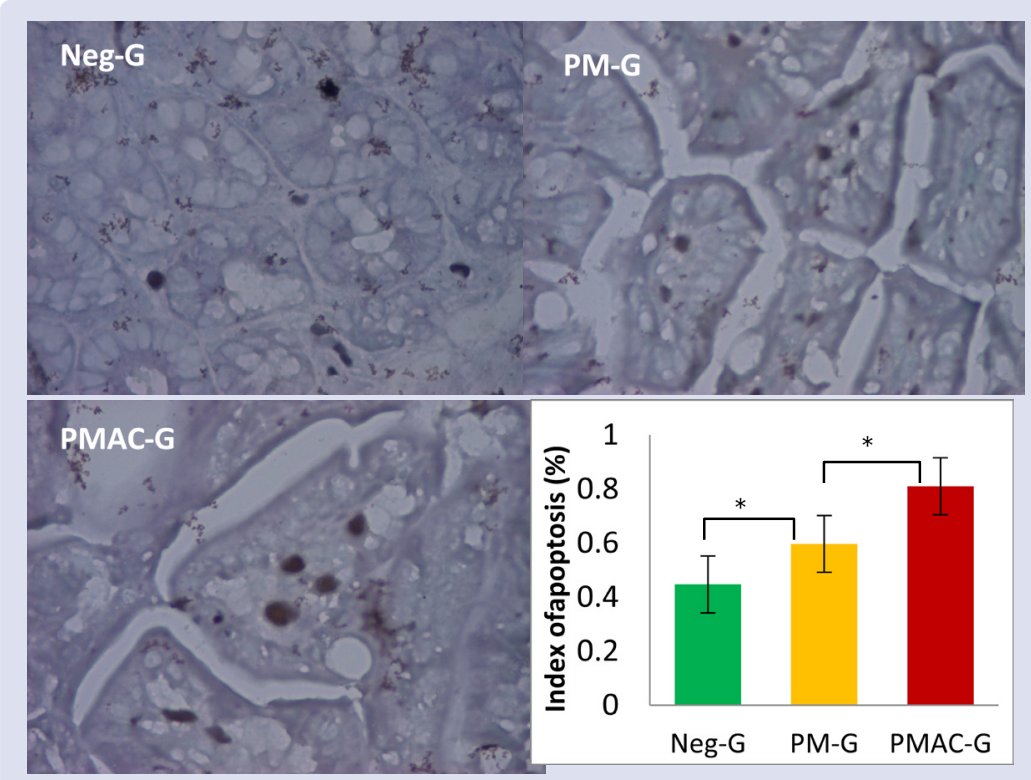

Figure 2: Index of apoptosis of Intestinal Mucous Cell was measured by TDEC staining methods. Mann Withney: ${ }^{*} p<0.05$.
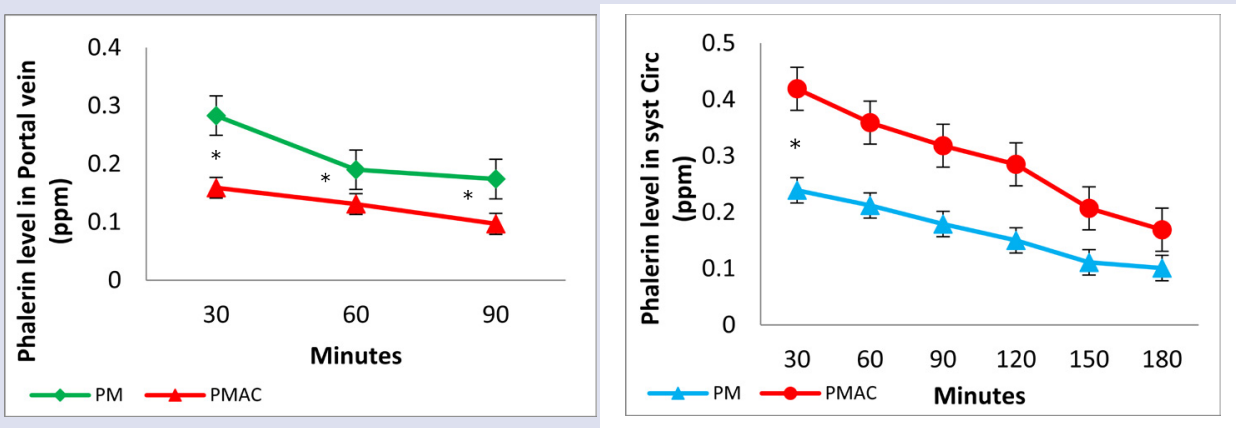

Figure 3: Phalerin concentration at systemic concentration at 30, 60, 90, 120, 150, and 150 minutes following treatment. *Independent $t$ test, $p<0.05$.

Table 3: Phalerin Concentration at Portal Vein Adenoma CH3 Female Mice Following PM and PMAC Treatment.

\begin{tabular}{cccc}
\hline $\begin{array}{c}\text { Phalerin Concentration } \\
\text { at portal vein } \\
(\mathbf{p p m})\end{array}$ & PM-G & Groups & $\begin{array}{c}\text { P } \\
\text { (independent t test) }\end{array}$ \\
\hline 30 & $0,283 \pm 0,741$ & PMAC-G & 0.002 \\
60 & $0,190 \pm 0,009$ & $0,159 \pm 0,005$ & 0.000 \\
90 & $0,174 \pm 0,007$ & $0,097 \pm 0,023$ & 0.000 \\
\hline
\end{tabular}

Table 4: Phalerin Concentration at Systemic Circulation in Adenoma CH3 Female Mice Following PM and PMAC Treatment.

\begin{tabular}{|c|c|c|c|}
\hline \multirow{2}{*}{$\begin{array}{l}\text { Phalerin Concentration in } \\
\text { systemic circulation } \\
(\mathrm{ppm})\end{array}$} & \multicolumn{2}{|c|}{ Groups } & \multirow{2}{*}{$\stackrel{\text { P }}{\text { (Independent t test) }}$} \\
\hline & $\begin{array}{c}P M-G \\
N=6 \quad X \pm S D\end{array}$ & $\begin{array}{l}\text { PMAC-G } \\
N=6 x+S D\end{array}$ & \\
\hline 30 & $0,239 \pm 0,088$ & $0,180 \pm 0,087$ & 0,060 \\
\hline 60 & $0,212 \pm 0,04$ & $0,147 \pm 0,017$ & 0,110 \\
\hline 90 & $0,179 \pm 0,196$ & $0,139 \pm 0,023$ & 0.025 \\
\hline 120 & $0,150 \pm 0,165$ & $0,135 \pm 0,010$ & 0,001 \\
\hline 150 & $0,111 \pm 0,020$ & $0,096 \pm 0,018$ & 0,012 \\
\hline 180 & $0,101 \pm 0,050$ & $0,068 \pm 0,025$ & 0,140 \\
\hline
\end{tabular}


hand, phalerin concentration in systemic circulation of PMAC-G was highest in minute 60 , followed by minute $90,120,30,150$, and the lowest was in minute 180 . These result showed that phalerin concentration in PMAC-G didn't declining in time fashion. However, independent $t$ test showed that phalerin concentration in $P M-G$ was significant higher compared to that of PMAC-G, $\mathrm{p}<0.05$ (Figure 3).

\section{Phalerin concentration at tumor tissues}

The result of phaleria concentration measurement with HPLC methods at minute 180 of systemic circulation and mice tumor tissues are summarized in Table 5 .

The result of the present study indicated that phalerin concentrations at minute 180 of PMT was higher significant compared to that of PMC, $\mathrm{p}<0.05$. Phalerin concentration at minute 180 of PMACT was higher compared to that of PMACC; however the difference was not significant, $\mathrm{p}>0.05$. Likewise, the phalerin concentration at minute 180 in PMC was not signicant lower compared to that of PMACT, $\mathrm{p}>0.05$ (Figure 4).

\section{DISCUSSION}

Phalerin or 3,4,5-dihydroxy,4'-methoxybenzophenone-3-O- $\beta$-Dglucoside was measured in the present sudy is a water soluble substance contained in PM. ${ }^{21,22}$ Hence in normal intestinal lining, phalerin can be absorbed passively by small intestine wall through paracellular route usually referred as intestinal permeability, and continuous toward portal vein and liver. ${ }^{23}$ In liver, phalerin directly undergo conjugation reaction without firstly being oxidized and hydrolyzed reaction and finally headed for systemic circulation. In systemic circulation, phalerin concentration may reflect the phalerin concentration at receptor site and its effect on cell and tissues. In addition to concentration, the phalerin effect on cells also determined by the receptor's density and its affinity to bind phalerin, subsequently determine its potency and efficacy. ${ }^{24}$ However, when the intestinal mucosal epithelium is damaged due to various causes including apoptosis, and therefore leading to cellular atrophy, it may decrease in intestinal permeability and subsequently reduce amount of nutrient or drug that can be absorbed as supported by the result of the present study.

The result of the present study demonstrated that phalerin concentration both at portal vein and systemic circulation of PM treatment alone were significant higher compared to that of PM treatment in combination with adriamicyne and cyclophosphamide. These result suggested that adriamycinee and cyclophosphamid, even in low dose, potentiate damage to intestinal mucous cell and therefore inhibit phalerin absorption. In the present study also indicated that the severity of intestinal mucous cell apoptosis and athropy in PM treatment in combination with adriamycine and cyclophosphamide were significant higher compared to that of PM alone. It is implayed that both adriamycine and cyclophosphamide clearly affect intestinal mucosal cell apoptosis and athropy. A study was reported by Guo P et al. showed that treatment with low dose cyclophosmaide cause damage to the intestinal mucous function barrier mediated by decreased in level of of interleukin- $10 .^{25}$ Another study was reported by Pette M, et al. also suggested that treatment with cyclophosphamide has been proven capable of inducing apoptosis in lymphocytes. ${ }^{12}$ Furthermore, a study was reported by Tiku $\mathrm{AB}$, et al. also in agreement with the previous study that cyclophosphamide induced DNA damage which could be inhibited by lemon juice orally. ${ }^{26}$ Finally, there are huge of evidences demonstrated that cyclophosphamide was proven able to induce damage

Table 5: Phalerin Concentration at minute 180 of systemic Circulation and Tumor Tissues in Adenoma CH3 Female Mice Following PM and PMAC Treatment.

\begin{tabular}{|c|c|c|c|c|c|}
\hline \multirow{3}{*}{$\begin{array}{l}\text { Phalerin Concentration } \\
\text { at minute } 180 \text { of Mice's } \\
\text { Syst Circ \& tumor tissues } \\
\text { (ppm) }\end{array}$} & \multicolumn{4}{|c|}{ Groups } & \multirow{3}{*}{$\begin{array}{c}\mathrm{P} \\
\text { (Indep t test) }\end{array}$} \\
\hline & \multicolumn{2}{|c|}{ Tumor mass } & \multicolumn{2}{|c|}{ Systemic Ciculation } & \\
\hline & $\begin{array}{c}\text { PM-G } \\
(x 0.164 \pm 0.046)^{*}\end{array}$ & $\begin{array}{c}\text { PMAC-G } \\
(x 0,116 \pm 0.097)^{*} ; * * *\end{array}$ & $\begin{array}{c}\text { PM-G } \\
(\times 0,101 \pm 0.050)^{* *}\end{array}$ & $\begin{array}{c}\text { PMAC-G } \\
(x 0,068 \pm 0.025)^{* * * * * *}\end{array}$ & \\
\hline 1 & 0.228 & 0.118 & 0.069 & 0.087 & \multirow{6}{*}{$\begin{array}{c}0.098^{\star} \\
0.234^{\star *} \\
0,057^{\star * *}\end{array}$} \\
\hline 2 & 0.209 & 0.075 & 0.020 & 0.059 & \\
\hline 3 & 0.150 & 0.097 & 0.186 & 0.074 & \\
\hline 4 & 0.116 & 0.103 & 0.112 & 0.029 & \\
\hline 5 & 0.167 & 0.224 & 0.098 & 0.058 & \\
\hline 6 & 0.116 & 0.080 & 0.123 & 0.101 & \\
\hline
\end{tabular}

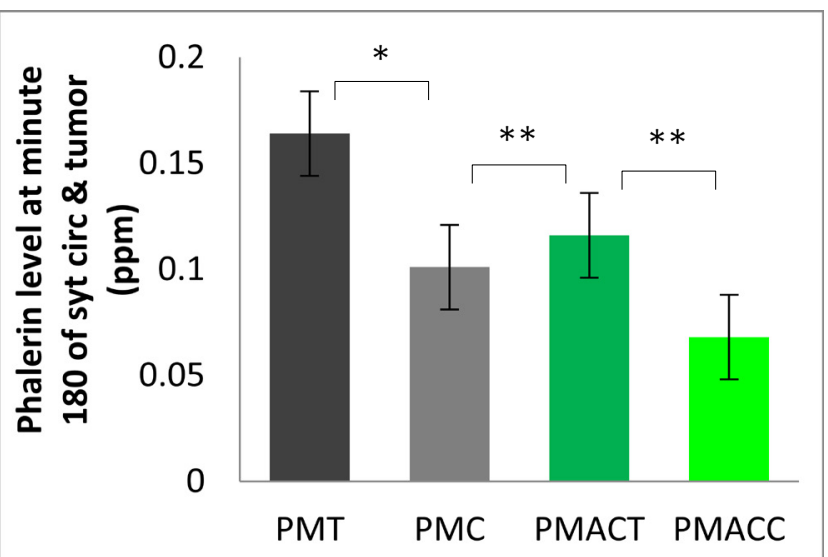

Figure 4: Phalerin Concentration at minute 180 of Systemic Circulation and Tumor mass. T test: ${ }^{*} p<0.05 ;{ }^{* *} p>0.05$. 

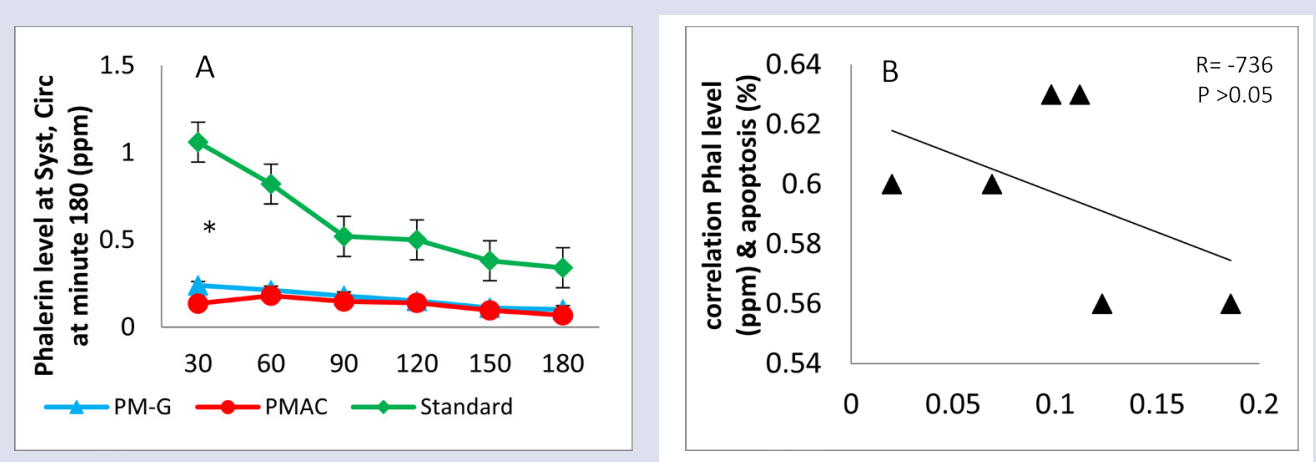

Figure 5: A. Phalerin concentration at systemic concentration at 30,60, 90, 120, 150, and 150 minutes following treatment. *Independent $t$ test, $p<0.05$; B. Correlation of Phalerin concentration in Systemic circulation \& intestinal index of apoptosis.

of various tissues such as liver, kidney, intestinal, cardiovascular, even induce amenorhae, early menopause, and hair loss. ${ }^{6,27}$

On the other hand, adriamycine also have been proven capable of inducing apoptosis in stem cell jejenum, followed by mucosal damage, decreased in crypt number caused by reduced proliferation, subsequently villus height. ${ }^{28} \mathrm{~A}$ study was done by Wang $\mathrm{S}$, et al. also displayed that adriamycine was able to induce apoptosis in endothelial cell and cardiomyocytes mediated by $\mathrm{p} 53$ and reactive oxygen species activation. ${ }^{29}$ Another study was reported by Ferreto, et al. also in agreement with the prior study that adriamycine was induce apoptosis mediated by decrease in anti-apoptotic $\mathrm{BCl}-2$ and increase in hydrogen peroxide and stress oxidative thereafter..$^{30}$ In this study also displayed that adriamycine treatment up regulate expression of protein proapoptosis such as Bax, caspase- 8 , and caspase- $-3 .^{30}$ In addition, an in-vitro study was reported by Oliveira MP, et al. demonstrated that treatment of adriamycine alone or in combination with cyclophosphamide have been proven posses high toxicity in cell particularly cardiomyocyte. ${ }^{31}$

Refer to the aforementioned data, subsequently can be implied that treatment with adriamycine alone or in combination with cyclophosphamide was very toxic to various cell and tissues. This toxicity was mediated by decreasing in mitochondrial potential membrane, down regulating anti-apoptosis protein expression such as $\mathrm{Bcl}-2$, and otherwise up regulating expression of protein proapoptosis such as Bax and particularly caspase- 3 which served as executor. Moreover, in the present study, phalerin concentration in systemic circulation of PM-G and PMAC-G were lower compared to that of gold standard of phalerin concentration. Therefore, the low phalerin concentration at portal vein and systemic circulation of PM treatment in combination with adriamycine and cyclophosphamid were associated with absorption disturbance caused by intestinal mucous cell apoptosis and therefore atrophy attributable to adriamycine and cyclophosphamid effect. However, the association between the concentration of phalerin in systemic circulation and the severity of intestinal mucous cell apoptosis and atrophy following PM treatment did not indicate inverse strong association (figure 5). This result strengthened the previous study that phalerin, a compound contained in PM possess protective effect to reduce destructive effect of adriamycine and cyclophosphamid on various tissues. $^{6}$

In conclusion, the result of the present study suggested that PM treatment in combination with adriamicyne and cyclophosphamide was able to induce apoptosis and atrophy at intestinal mucous cell and therefore decrease phalerin absorption by intestinal wall. However, the inverse correlation between phalerin concentration and the severity of intestinal mucous cell apoptosis did not exist.

\section{REFERENCES}

1. Jnr FNG, Anyanful A, Eliason S, Adamu SM, Debrah S. Pattern of breast cancer distribution in ghana: a survey to enhance early detection, diagnosis, and treatment. International Journal of Breast Cancer. 2016;1-9.

2. Anjum F, Razvi N, Masood MA. Breast Cancer Therapy: A Mini Review. MOJ Drug Des Develop Ther. 2017;1(2):00006.

3. Yi SY, Seok JA, Uhm JE, Lim DH, Ji SH, Jun HJ, Kim KH, et al. Favorable respone to doxorubicin combination chemotheraphy does not yield good clinical outcome in patient with metastatic breast cancer with triple negatif phenotype. Bio Med Central Cancer. 2010;10;527.

4. Nurgali K, Jagoe RT, Abalo R. Editorial: Adverse effects of Cancer Chemotherapy Anything New to Improve Tolerance to Reduce Sequele? Front Pharmacol. 9:245

5. Aslam MS, Naveed S, Ahmed A, Abbas Z, Gull I, Athar MA. Side Effects of Chemotherapy in Cancer Patients and Evaluation of Patients Opinion about Starvation Based Differential Chemotherapy. Journal of Cancer Therapy. 2014;5:817-22.

6. Riwanto I, Prasetyo SA, Budijitno S, Dharmana E, Handojo D, Eko A, et al. Effect of Phaleria Macrocarpa Supplementation on Apoptosis and Tumor Growth of C3H Mice with Breast Cancer Under Treatment With AdriamycineCyclophosphamide. Int Surg. 2011;96:164-70.

7. Arif IS, Hooper CL, Greco F, Williams AC, Boateng SY. Increasing doxorubicin activity against breast cancer cells using PPARy-ligands and by exploiting circadian rhythms. British Journal of Pharmacology. 2013;169:1178-88.

8. Cao B, Li M, Zha W, Zhao Q, Gu R, Liu L, et al. Metabolomic approach to evaluating adriamycin pharmacodynamics and resistance in breast cancer cells. Metabolomics. 2013;9:960-73.

9. Taskin E, Dursun N. Recovery of adriamycin induced mitochondrial dysfunction in liver by selenium. Cytotechnology. 2015;67:977-86

10. Crom WR, Glynn-Barnhart AM, Rodman JH, et al. Pharmacokinetics of Anticancer Drugs in Children. Clinical Pharmacokinetics. 1987;12:179-82.

11. Crook TR, Souham RT,Cytotoxicity, DNA cross-linking, and single strand breaks induced by activated cyclophosphamide and acrolein in human leukemia cells. Cancer Res. 46,1986,5029-34.

12. Pette M, Gold R. Mafosfamide induces DNA fragmentation and apoptosis in human T-lymphocytes. A possible mechanism of its immuno-suppressive action. Immunopharmacology. 1995;30:59-69.

13. Selby PJ, Lopes N, Mundy J, Crofts M, Millar JL, McElwainTJ. Cyclophosphamide priming reduces intestinal damage in man following high dose melphalan chemotherapy. Br J Cancer. 1987;55:531-3.

14. Keefe DM, Brealey J, Goland GJ, Gummin AG. Chemotheraphy for cancer cause apoptosis that precedes hypoplasia in crypt of small intestin in human. Gut. 2000;47:632-7.

15. Rodrigues D, Souza T, Jennen DGJ, Lemmens L, Kleinjans JCS, de Kok TM. Drug-induced gene expression profile changes in relation to intestinal toxicity: State-of-the-art and new approaches. Cancer Treatment Reviews. 2019;77:5766.

16. Tandrasasmita OM, Lee JS, Baek SH, Tjandrawinata RR. Induction of cellular apoptosis in human breast cancer by DLBS1425, a Phaleria macrocarpa compound extract, via down-regulation of PI3kinase/AKT pathway. Cancer Biology \& Therapy. 2010;10:8,814-23.

17. Kaczmarek A, Brinkman BM, Heyndricckx L, Vanddenabeele P, Krysko DV. Severity of doxorubcin induced small intestinal mucocitis is regulated by the TLR-2 and TLR-8 pathways. The journal of Pathology. 2012;226(4):598-608. 
18. Homayun B, Lin X, Choi HJ. Challenges and Recent Progress in Oral Drug Delivery Systems for Biopharmaceuticals. Pharmaceutics. 2019;11:129.

19. Macpherson BR, Pfeiffer CJ: Experimental production of diffuse colitis in rats. Digestion. 1978;17:35-50

20. Leitao RFC, Brito GAC, Oria RB, Neto MBB, Bellaguarda EAL, Silva JV, et al. Role of inducible nitric oxide synthase pathway on methotrexate-induced intestinal mucositis in rodents. BMC Gastroenterology. 2011;11:90.

21. Hartati MSW, Mubarika S, Gandjar IG, Hamann MT, Rao KV, Wahyuono S. Phalerin, a new benzophenoic glucoside isolated from the methanolic extract of Mahkota Dewa [Phaleria macrocarpa (scheff). Boerl.] leaves. Mae Sri Hartati W. Majalah Farmasi Indonesia. 2005;16(1):51-7.

22. Altaf R, Asmawi MZ, Dewa A, Sadikun A, Umar MI. Phytochemistry and medicinal properties of Phaleria macrocarpa (Scheff.) Boerl. Extracts. Pharmacognosy Reviews. 2013;7(13):73-80.

23. Vertzoni M, Augustijns P, Grimm M, Koziolek M, Lemmens G, Parrot N, et al. Impact of regional differences along the gastrointestinal tract of healthy adults on oral drug absorption: An UNGAP review. European Journal of Pharmaceutical Sciences. 2019;134:53-75.

24. Boger E, Evans N, Chappell M, Lundqvist A, Ewing P, Wigenborg A, Friden M. Systems Pharmacology Approach for Prediction of Pulmonary and Systemic Pharmacokinetics and Receptor Occupancy of Inhaled Drugs. CPT Pharmacometrics Syst Pharmacol. 2016;5:201-10.
25. Guo P, Tang ST, Zhang SW, Zhang J, Dong JT, Wu JD, et al. Effects of imipenem combined with low-dose cyclophosphamide on the intestinal barrier in septic rats. Experimental and Therapeutic Medicine. 2018;16:1919-27.

26. Tiku AB, Abraham SK, Kale RK. Protective Effect of The Cruciferous Vegetable Mustard Leaf (Brassica Campestris) Against In Vivo Chromosomal Damage and Oxidative Stress Induced by Gamma-Radiation And Genotoxic Chemicals. Environ Mol Mutagen. 2008;49:335-42.

27. Teles KA, Souza PM, Lima FAC, de Araujo BG, Lima RAC. Cyclophosphamide administration routine in autoimmune rheumatic diseases: a review. Rev Bras Reumatol. 2017;57(6):596-604.

28. Dekaney CM, Gulati AS, Garrison AP, Helmrath MA, Henning SJ. Regeneration of intestinal stem/progenitor cells following doxorubicin treatment of mice. Am J Physiol Gastrointest Liver Physiol. 2009;297:G461-G70.

29. Wang S, Konorev EA, Kotamraju S, Joseph J, Kalivendi S, Kalyanaraman B. Doxorubicin Induces Apoptosis in Normal and Tumor Cells via Distinctly Different Mechanisms. 2004;279(24):25535-43.

30. Ferreto NP, Calaf GM. Influence of doxorubicin on apoptosis and oxidative stress in breast cancer cell lines. International Journal of Oncology. 2016;49:753-62.

31. Oliveira MP, Mendes AR, Carvalho F, Remiao F, Bastos ML, Costa VM Doxorubicin Is Key for the Cardiotoxicity of FAC (5-Fluorouracil + Adriamycine + Cyclophosphamide) Combination in Differentiated H9c2 Cells. Biomolecules. 2019;9(21):2-20.

\section{GRAPHICAL ABSTRACT}
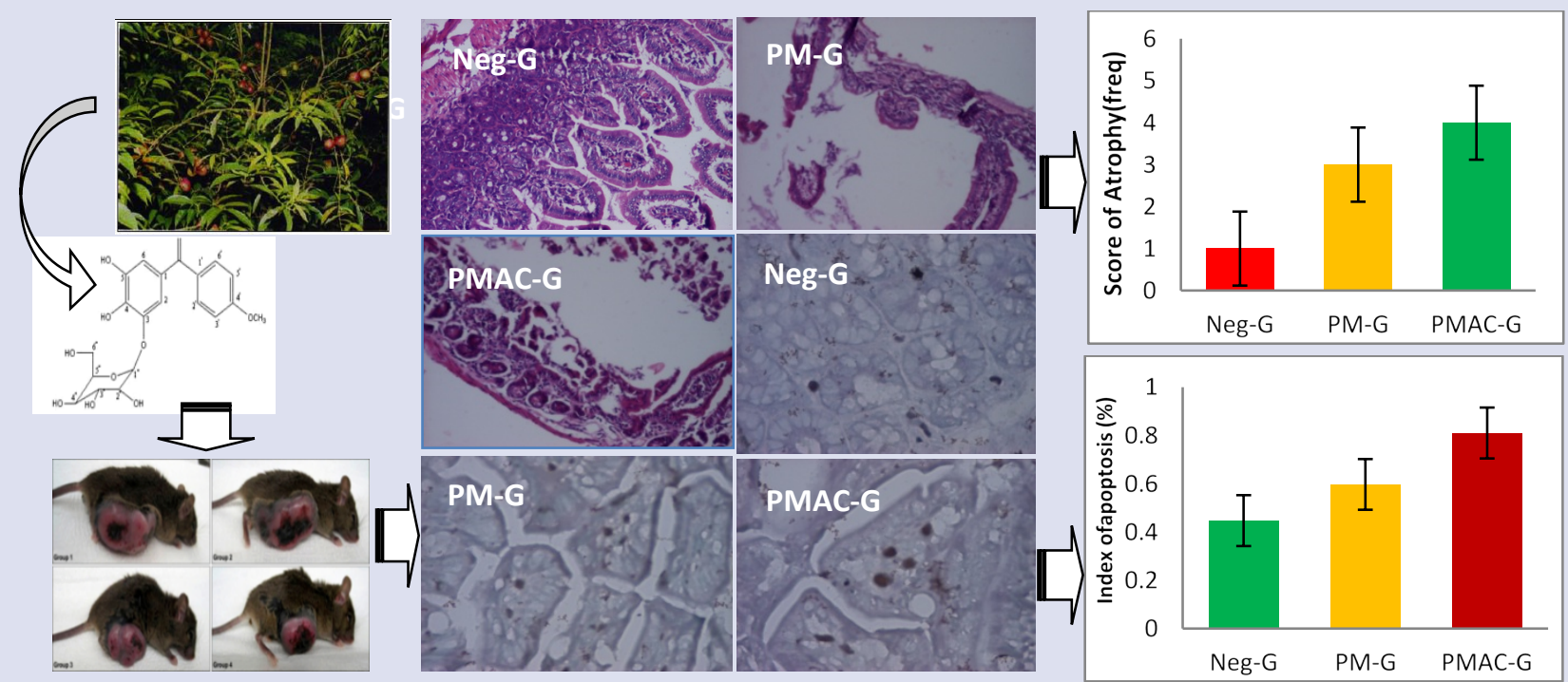

\section{ABOUT AUTHORS}

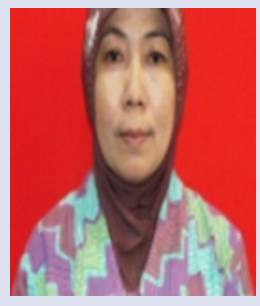

Titiek Sumarawati, received her doctoral degree at Diponegoro University Semarang in 2012. She is currently a lecturer at Universitas Islam Sultan Agung Semarang Indonesia. Her research interests are medicinal chemistery and drug discovery.

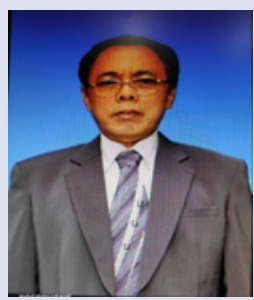

IGN. Riwanto, Professor in digestive surgery Dr. Karyadi Hospital Semarang, received his PhD at Free University Amsterdam in 1992. He is consultant of digestive surgeon in Dr Kariadi and St Elizabeth hospital. Also, lecturer of undergraduate (surgery) and postgraduate (specialist trainer in general surgery, sub-specialist trainer in Digestive Surgery, Master of Biomedical and Medical/Health Doctorate program). 


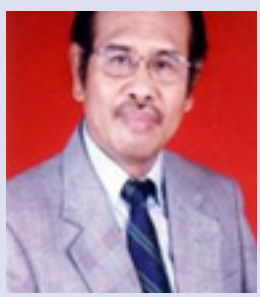

Suharyo Hadisaputro, Professor in medicine medical faculty Diponegoro univeersity. He is specialist in internal Medicine and consultant of tropical infectious diseases. Also chief of reseacher tropical infectious disease and concern in epidemiology of comunicable and noncomunicable diseases.

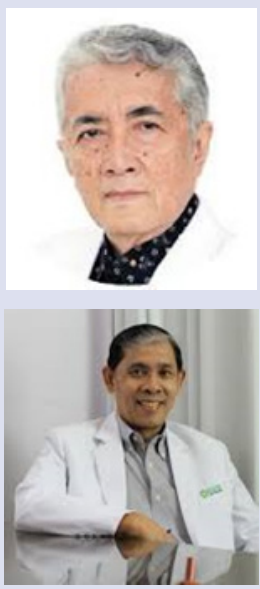

Edi Dharmana, Professor in immunology, received his PhD at Radboud University Nijmegen Netherlands. $\mathrm{He}$ is specialist in clinical parasitology, consultan, and lecturer in clinical immunology, also reseacher in botanical product.

Taufiqurrachman Nasihun, Professor in medicine. Received his doctoral degree at Diponegoro university Semarang in 2007. He is specialist in andrology, consultant in sex and antiaging medicine, and concern in medical biochemistry. He is also lecturer in medical biochemtery of medical faculty, Universitas Islam Sultan Agung and reseacher in botanical product.

Cite this article: Sumarawati T, Riwanto I, Hadisaputro S, Dharmana E, Nasihun T. Effect of Phaleria macrocapa on Atrophy and Apoptosis of Intestinal Mucous Cell and Phalerin Concentration at Portal Vein and Systemic Circulation in Adenocarcinoma Mice following Adriamycine and CyclophosphamideTreatment. Pharmacog J. 2020;12(3):603-10. 